ticといえる。

次に手術により治虑した症例は群化型 8 例，抑制型 9 例, 正常型 2 例, 持続型 1 例に対し, 治痖程度が貧 弱な例では群化型 1 例，抑制型 5 例であった。結論と して，まず spastic 型と spasmodic 型の両者が筋電図 学時に証明されたこと。従って, 痓變性発声障言は筋 電学的に診断名をつけるべきかと考えられた，治療し ていく確率からみると, spastic も spasmodic も同率 で治瘾するが, 治りがたい方から眺めると, spastic の 方が治り難い傾问にある。質問 磯貝 豊(東京電 力). TA の EMGが抑制性なのに声は spasticで声門
も強直しいるのは何故なのか. 答、疗攀発声に 同期して，内嗼頭筋や軟口蓋からとられた筋活動が抑 制される所見をえているけれども，何故そのような沏 制が生じるのか, 背景となっているメカニズムについ ては不明である。質問 牛島達次郎(查京聥信)。 群化型と抑制型とは，会話音声を聴いた際に区別がつ くものかどうか，応答 瘃戀性発声障害患者の大 部分は, 普通会話と持続発声の両条件で, 㾏樂様音声 所見をみる。しかし，会話時に声の途切れがあれど， 母音の持続発声では途切れがみられる例が，自験例30 例中 1 例ぐらいはあったと思う。

\title{
187 ポリープ様声帯の発声機能と聴覚的印象
}

\section{（重症度別検討）}

\author{
柴 裕子（柴耳鼻咽喉科）溝层源太郎（みぞじりクリーック） \\ 野崎智嗣（兵庫県立成人病センター）
}

ポリープ樣声帯の発声機能は, 手術により術後 1 力 月では济正常化するが, 聴賞的印象は術後 6 力月まで 回復が続くものの、軽度の嗄声が残ることを既に報告 した。今回はさらに，病型別に分けて報告した。

対象と方法 ラリンゴマイクロサージェリーを行っ た54例（米川分類 I 型15例，II型22例，III型17例）を， 性差は考慮にい机ず病型別に比較した, 発声機能検査 は, 永島医科のPS-77 を使用し, 無関位発声時の発声 持続時間, 起声時呼気流率, 持続発声時呼気流率, 音 圧，基本周波数を測定した。聴覚的印象は 2 名の耳鼻 咽喉科医が評価し，その平均をとつた。評価方法は， 正常な声を10点，もつとも強い嗄声を 1 点として10段 階で評価する総合評価“T”と，日本音声言語医学会の “GRBAS” 尺度で行った。

結果 A・発声機能 発声持続時間では I II 型と III型, 起声時呼気流率ではI 型とIII型, また基本周波 数では I 型上II，III型の間に有意差があり，おおむ双 I, II, III型の順に悪化している。手術により, I 型 では起声時及び持続発声時呼気流率のみだが，II 型， III型では 5 項目すべてが有意に改善した。B 聴賞心
理的印象 I, II, III型の順にRBS が強くなり TGも 悪化している。手術により I 型は改善せず，II型では TGRB，III型ではTGRBSが有意に改善した。

まとめと考察 病変の程度に応じて発声機能や聴賞 的印象が悪化して扔り，II型，III型住明らかな改善が 得られ良い手術適応だが，I 型は手術による改善が余 り期待できないことが分かった。今回の対象症例法， 音声治療を行って扔らず, 手術単独療法の限界を示し ている。米川も，I 型，II型の手術適応は慎重に決め る心゙きだとしている。手術の適応と限界が分かりかけ てきた今，音声治療を含屯徹底した保存的治療の適応 と限界を知ることも，本疾惠の治療法の確立のために 必要である。質問 山口宏也(東京専売)。術後の 薬物治療は何をよ゙の位の期間内行っているのか。 応答 術後の薬物治療としては, 術後 $1 \sim 2$ 週間程度 で抗生剂の投与在行っている。追加平野実 (久留米大)。大变良い研究である。デー夕は持続発声 や呼気流率についての機能の回復の方が, 良い声を出 声機能の回復上り早い上解説するのがよい。

\section{8. 声带ポリープの発声機能と聴賞的印象} 重症度別検討

\section{野崎智翤・井上健造 星野鉄雄・山田康荘（兵庫県立成人病センター） 溝尻源太郎（みぞじりクリニック）柴 裕子(柴耳鼻咽唉科)}

声带ポリープの大きさ，位置，形状が発声機能や聴 賞的印象に及ほす影響党検討した。

対象の方法 対象は一側性声带・ポリープ53例（広 基性32例，半球性・有茎性21例）である。発声機能検 直は永島医料の PS-77 を使用し, 無関位発声時
持続時間, 起声時呼気流率, 持続発声時呼気流率, 音 圧，基本周波数を測定した，聴賞的印象は 2 名の耳鼻 咽喉科医が評価し，その平均をとった。評価方法は， 正常な声を10点, 最も強い嗄声を1点として10段階評 洒する総合評洒 “ $\mathrm{T}$ ” と, 日本音声言語医学会の 